\title{
NOx REMOVAL FROM AIR THROUGH SUPER HYDROPHOBIC HOLLOW FIBER MEMBRANE CONTACTORS
}

\author{
Sutrasno Kartohardjono ${ }^{1 *}$, Nelson Saksono ${ }^{1}$, Dijan Supramono ${ }^{2}$, Popphy Prawati ${ }^{1}$ \\ ${ }^{1}$ Process Intensification Laboratory, Department of Chemical Engineering, Faculty of Engineering, \\ Universitas Indonesia, Kampus UI Depok, Depok 16424, Indonesia \\ ${ }^{2}$ Thermodynamic, Energy and Environmental Laboratory, Department of Chemical Engineering, \\ Faculty of Engineering, Universitas Indonesia, Kampus UI Depok, Depok 16424, Indonesia
}

(Received: July 2018 / Revised: October 2018 / Accepted: April 2019)

\begin{abstract}
NOx, a generic term for nitrogen oxides, is an air pollutant that can causes damage to the ozone layer, and produces greenhouse effects, acid rain and photochemical smog. It is mainly produced by diesel engine exhaust due to the reaction between nitrogen and oxygen, especially at elevated temperatures. NOx needs to be reduced from flue gas in order to fulfil environment regulations due to its hazardous nature. This study aims to remove NOx from air through absorption using a mixture of $\mathrm{H}_{2} \mathrm{O}_{2}$ and $\mathrm{HNO}_{3}$ solutions as an absorbent in the membrane contactors. In the experiment, the feed gas and the absorbent were flowed in the shell side and the lumen fibers, respectively. The flow rates of absorbent and feed gas, as well as the fiber number the membrane contactor, greatly influence the efficiency of NOx removal, mass transfer coefficients and fluxes. The highest values of NOx removal efficiency, mass transfer coefficient and flux achieved in the study were $47 \%, 8.7 \times 10^{-5} \mathrm{~cm} \cdot \mathrm{sec}^{-1}$, and $3.1 \times 10^{-5} \mathrm{mmole} . \mathrm{cm}^{-2} \cdot \mathrm{sec}^{-1}$, respectively.
\end{abstract}

Keywords: Air pollutant; Flux; Mass transfer coefficient; Membrane contactors; Nitrogen oxides

\section{INTRODUCTION}

Nitrogen oxides (NOx), besides $\mathrm{CO}_{2}$, are key pollutants in the flue gas emitted from the fossil fuel combustion process, and are very hazardous, having harmful effects on the human and global environment, such as damage to the ozone layer, greenhouse effects, formation of acid rain and photochemical smog (Wang et al., 2012; Wang et al., 2014; Zhang et al., 2014; Bueno-López et al., 2016; Ahmad et al., 2017; Yu et al., 2017; Cheng et al., 2018; Nimcharoen et al., 2018). Diesel engines are among the main contributors of NOx emissions into the atmosphere (Zhu et al., 2008; Choi \& Lee, 2014; Cheng et al., 2018). Demand for diesel-engined vehicles is steadily growing due to an increase in their fuel consumption efficiency of 20-30\% over gasoline vehicles (Li et al., 2009; Choi \& Lee, 2014). However, around $80 \%$ of the NOx emitted is from such vehicles (Zouzelka \& Rathousky, 2017). The formation of NOx in a diesel engine is due to the presence of a mixture of air and fuel at high pressure which produces NO, which will react further with oxygen to form $\mathrm{NO}_{2}$. The mixture of $\mathrm{NO}$ and $\mathrm{NO}_{2}$ is called $\mathrm{NOx}$ (Li et al., 2016).

Some methods have been exploited for NOx removal, such as selective catalytic reduction (SCR), selective non-catalytic reduction (SNCR), adsorption and absorption (Zhao et al., 2007). However, the temperature applied in the above technologies is high, typically $300-500^{\circ} \mathrm{C}$ for

\footnotetext{
${ }^{*}$ Corresponding author's email: sutrasno@che.ui.ac.id, Tel. +62-21-7863516, Fax. +62-21-7863515

Permalink/DOI: https://doi.org/10.14716/ijtech.v10i3.2907
} 
SCR, due to catalyst efficiency, while the exhaust temperature of much heat transfer equipment lies below the working temperature of industrial SCR technology (Herreros et al., 2014). For decades, the development and application of catalytic technology for lowering NOx have grown considerably due to ever stricter emission standards (Bueno-López et al., 2016). The catalytic removal of NOx is based on two methods, NOx SCR and NOx NSR (Granger \& Parvulescu, 2011; You et al., 2018). NOx reduction through SCR is the most mature and efficient technology for reducing $\mathrm{NOx}$; it uses vanadium supported on titanium with $\mathrm{WO}_{3}$ or $\mathrm{MoO}_{3}$ as catalyst promoters (Dvořák et al., 2010. The NSR process is an alternative technology for NOx reduction, in which a storage material is utilized to chemisorb NOx, and a reducing agent is regularly fed, which will reduce the chemisorbed species to $\mathrm{N}_{2}$ (Li et al., 2016). The catalysts for NSR are basically composed of an alkali or alkali-earth oxide and a noble metal impregnated on alumina (Epling et al., 2004; Pereda-Ayo et al., 2009). NOx can also be absorbed into an acidic solution with $\mathrm{H}_{2} \mathrm{O}_{2}$ through the absorption-reaction mechanism (Liémans \& Thomas, 2013):

$$
\begin{gathered}
2 \mathrm{NO}_{2} \leftrightarrow \mathrm{N}_{2} \mathrm{O}_{4} \\
\mathrm{NO}+\mathrm{NO}_{2} \leftrightarrow \mathrm{N}_{2} \mathrm{O}_{3} \text { (and in the presence of water } \mathrm{NO}+\mathrm{NO}_{2}+\mathrm{H}_{2} \mathrm{O} \leftrightarrow 2 \mathrm{HNO}_{2} \text { ) } \\
3 \mathrm{HNO}_{2} \leftrightarrow \mathrm{HNO}_{3}+\mathrm{H}_{2} \mathrm{O}+2 \mathrm{NO} \\
\mathrm{HNO}_{2}+\mathrm{H}_{2} \mathrm{O}_{2} \leftrightarrow \mathrm{HNO}_{3}+\mathrm{H}_{2} \mathrm{O}
\end{gathered}
$$

$\mathrm{H}_{2} \mathrm{O}_{2}$ is added to the liquid phase to prevent decomposition of $\mathrm{HNO}_{2}$ (3) by oxidation into $\mathrm{HNO}_{3}$ and to improve the mass transfer rate of $\mathrm{HNO}_{2}$ in the gas phase, following reaction (4), while the addition of $\mathrm{HNO}_{3}$ will enhance this reaction (Liémans \& Thomas, 2013). This study employed super hydrophobic micro porous hollow fiber membrane contactors to reduce NOx, using a mixture of $\mathrm{HNO}_{3}$ and $\mathrm{H}_{2} \mathrm{O}_{2}$ solution as absorbent. Super hydrophobic fibers were used to avoid membrane wetting by the absorbents and to prevent the drop on the mass transfer coefficient. The effects of gas and absorbent flow rates on NOx reduction in the gas phase were evaluated. The advantage of the proposed method is that the process can be conducted at room temperature.

\section{MATERIALS AND METHODS}

\subsection{Materials}

A schematic diagram of the experimental set up is presented in Figure 1, which has previously been published elsewhere (Kartohardjono et al., 2016; Kartohardjono et al., 2017a). Three membrane modules were used in the experiment, $6 \mathrm{~cm}$ and $34 \mathrm{~cm}$ in diameter and length, respectively. The modules were provided by PT GDP Filter Bandung Indonesia. The fibers were sized 145 and $235 \mu \mathrm{m}$ in thickness and inner diameter, respectively, and were polypropylenebased. The NOx (600 ppm in air) and $65 \mathrm{wt} \% \mathrm{HNO}_{3}$, as well as $35 \mathrm{wt} \% \mathrm{H}_{2} \mathrm{O}_{2}$, were purchased from PT Energi Indogas Nusantara and Merck Indonesia, respectively.

\subsection{Methods}

During the experiment, an absorbent consisting of $0.5 \mathrm{M} \mathrm{HNO}_{3}$ and $0.5 \mathrm{wt} \% \mathrm{H}_{2} \mathrm{O}_{2}$ solution $1: 1$ was pumped into the interior fibers, while the feed gas containing NOx flowed into the contactor on the shell side. The flow rate of the feed gas to the contactor was regulated using a mass flow controller CX Series from Shanghai Cixi Instrument, while NOx concentrations in the inlet and outlet streams were measured using an NOx meter from Gas Tiger 2000 China. 


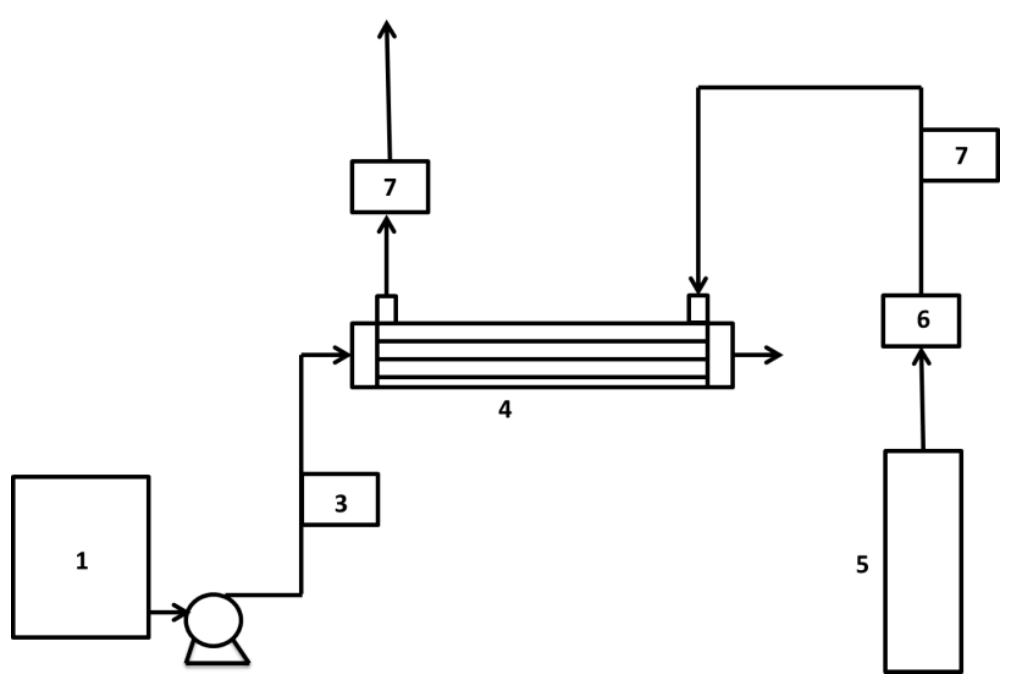

Figure 1 Experiment set-up and apparatus: 1. Absorbent reservoir; 2. Pump; 3. Liquid flow meter; 4. Hollow fiber membrane module; 5. Feed gas tank; 6. Mass flow controller; 7. NOx meter

The quantity of NOx absorbed, $\mathrm{NOx}_{\mathrm{abs}}$, and the absorption efficiency, $\% R$, can be derived by material balanced, as shown in Equation 5 and Equation 6, respectively:

$$
\begin{aligned}
& N O x_{a b s}=\left(x_{i}-x_{o}\right) Q_{G} \frac{P}{R T} \\
& \% R=\frac{\left(x_{i}-x_{o}\right)}{x_{i}} 100 \%
\end{aligned}
$$

where $x_{\mathrm{i}}$ and $x_{\mathrm{o}}$ are NOx concentrations in the inlet and outlet gas to and from the membrane contactor, respectively, while $Q_{\mathrm{G}}, P, R$ and $T$ are the feed gas flow rate, pressure, gas constant and temperature, respectively. Meanwhile, the overall mass transfer coefficient, $K_{\mathrm{OVL}}$, and the flux, $J$, were calculated using Equation 7 and Equation 8, respectively (Wang et al., 2004):

$$
\begin{aligned}
& K_{O V L}=\frac{Q_{G}}{A m} \ln \left(\frac{x_{i}}{x_{o}}\right) \\
& J=\frac{N O x_{a b s}}{A m}
\end{aligned}
$$

where $A m$ is the membrane fiber surface area in the contactor.

\section{RESULTS AND DISCUSSION}

The NOx transfer mechanism in the contactor followed three steps: the transfer of NOx from the bulk gas into the membrane surface in the gas phase; the transfer of NOx through the membrane pores into the membrane surface in the liquid phase; and the transfer of NOx into the bulk absorbent. Therefore, the transfer of NOx into the membrane contactor can be expressed as mass transfer through a model of three series of resistance, i.e. in the gas phase, membrane pores and absorbent phase. The amount of NOx absorbed, as well as the NOx flux through the membrane contactor, increased with the absorbent flow rate due to an increase in absorbent boundary layer turbulence, which caused a decrease in mass transfer resistance in the absorbent phase, as presented in Figure 2 (Li \& Chen, 2005; Franco et al., 2008). Figure 2 shows that the NOx absorbed increases with the increasing number of membrane fibers in the contactor, while it decreases for flux due to the increase in the gas-liquid contact surface area (Kartohardjono et al., 2016). 


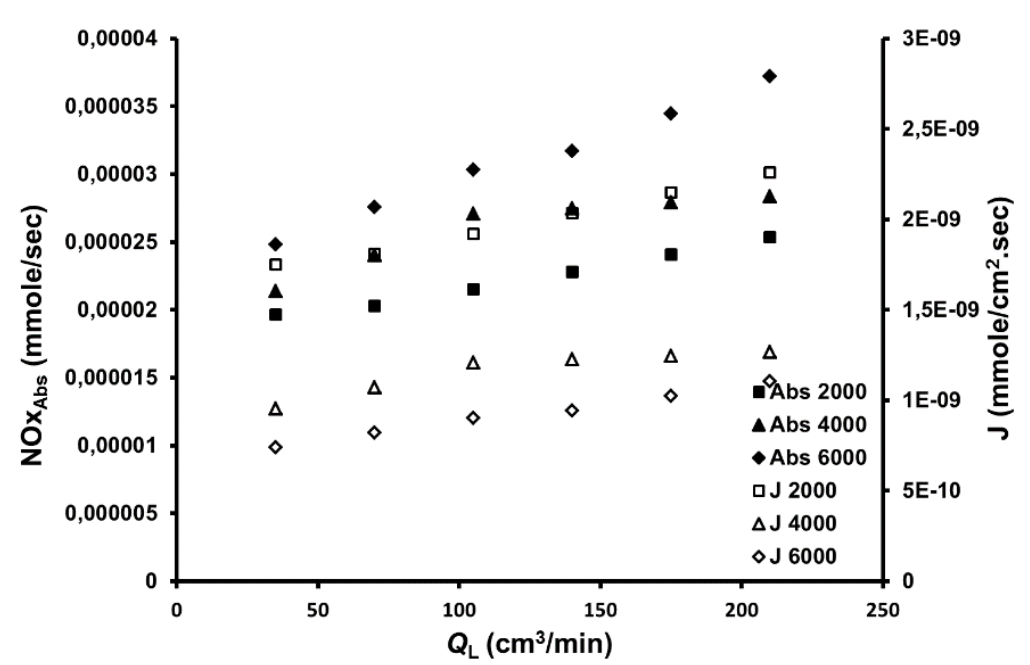

Figure 2 Effects of absorbent flow rate, $Q_{\mathrm{L}}$, on the amount of NOx absorbed, NOx $\mathrm{Abs}_{\text {, }}$, and flux, $J$, in the membrane contactors consisting of 2000, 4000 and 6000 fibers

The liquid phase mass resistance is the largest resistance for the NOx transfer through the membrane contactor (Wang et al., 2004). It can be seen that the NOx transfer was enhanced by increasing the absorbent flow rate in the contactor, as presented in Figure 3. Flow turbulence will be enhanced by increasing the absorbent flow rate, thereby reducing the liquid phase resistance and increasing the mass transfer coefficient (Dindore et al., 2005; Kartohardjono et al., 2017a). The phenomenon of the increase in the overall mass transfer coefficient in line with the increasing absorbent flow rate indicates that the membrane is not wetted (Wang et al., 2004). The effect of fiber number on the mass transfer coefficient in the membrane contactor is also presented in Figure 3. Increasing the number of fibers will produce two effects, namely an increase in the surface area for gas-liquid contacts on one side, and on the other side a reduction in the absorbent flow rate in a single fiber. Increasing the gas-liquid contact area will enhance the amount of NOx absorbed, while a decrease in the absorbent flow rate will reduce the amount of NOx that can be absorbed through the membrane contactor. Figure 3 shows that an increase in fiber number decreases the overall mass transfer coefficient, indicating that absorbent flow rate has a more dominant effect than surface area (Kartohardjono et al., 2017b).

Figure 4 shows the dependence of NOx removal efficiency on the absorbent flow rate in the contactors consisting of 2000, 4000 and 6000 fibers. As with the amount of NOx absorbed, NOx removal efficiency increases with an increase in the absorbent flow rate due to increased flow turbulence. NOx removal efficiency also improves with an increase in the number of fibers in the contactor, as the contact surface area also increases. In this study, the efficiency of NOx removal increased from 25 to $47 \%$ by increasing the absorbent flow rate from 35 to $210 \mathrm{~cm}^{3} / \mathrm{min}$. Similar results were also obtained by Kartohardjono et al. (2017b) for the absorption of $\mathrm{CO}_{2}$ using 5 vol.\% of DEA solution as absorbent, in which case the efficiency $\mathrm{CO}_{2}$ absorption increased from 93.9 to $96.2 \%$ by increasing the absorbent flow rate from 100 to $500 \mathrm{~cm}^{3} / \mathrm{min}$. 


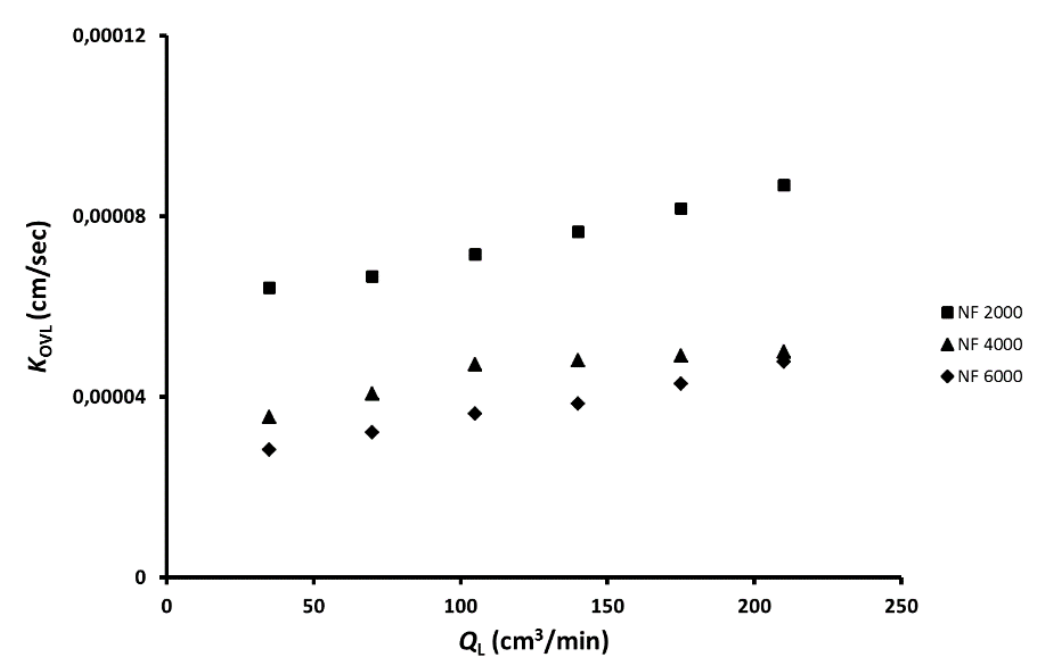

Figure 3 Effects of absorbent flow rate, $Q_{\mathrm{L}}$, on the overall mass transfer coefficient, $K_{\mathrm{OVL}}$, in the membrane contactors consisting of 2000, 4000 and 6000 fibers

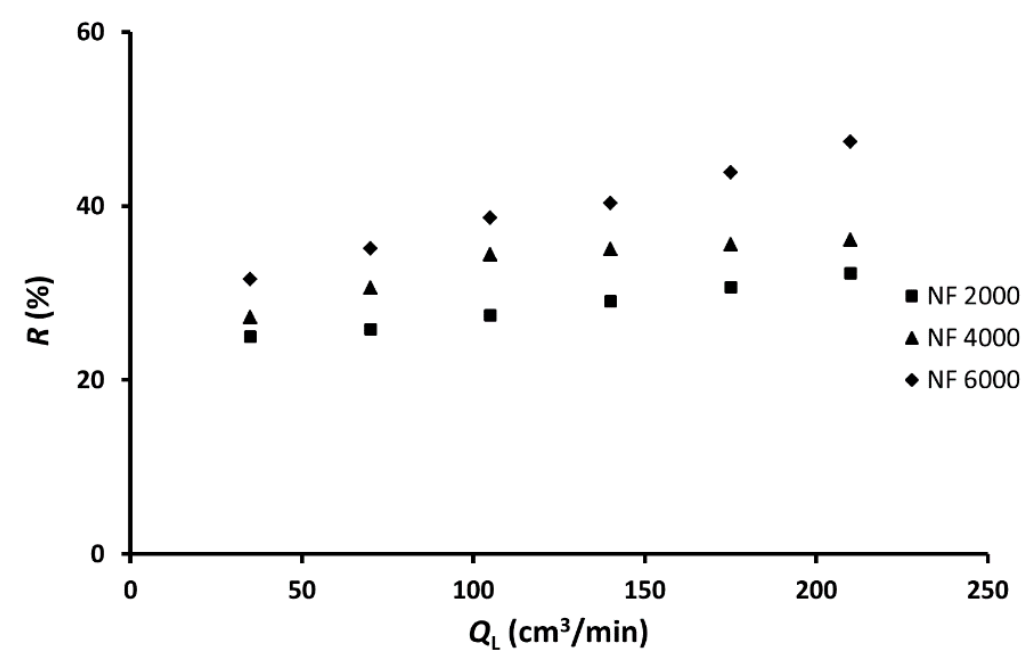

Figure 4 Effects of absorbent flow rate, $Q_{\mathrm{L}}$, on NOx removal efficiency, $R$, in the membrane contactors consisting of 2000, 4000 and 6000 fibers

Figure 5 shows the effect of feed gas flow on the amount of NOx absorbed in a contactor containing 2000 fibers. An increase in this rate will enhance the amount of NOx absorbed, as the turbulence in the gas phase will reduce mass transfer resistance. The increase in NOx absorbed was also followed by an increase in NOx flux through the membrane fibers in the contactor at the same amount of fibers used in the experiment.

Figure 6 shows the impact of feed gas rate on the mass transfer coefficient on a contactor containing 2000 fibers. Increasing the rate will enhance the mass transfer coefficient because of the increase in the amount of NOx that can be absorbed. There was an increase from 36 to $42 \%$ for the overall mass transfer coefficient when the feed gas rate was increased from 100 to 200 $\mathrm{cm}^{3} / \mathrm{min}$. A similar phenomenon of increasing the mass transfer coefficient with the feed gas flow rate has been previously reported (Kartohardjono et al., 2017b) for the absorption of $\mathrm{CO}_{2}$ using a DEA 5 vol.\% solution absorbent, in which case there was an increase from 66 to $74 \%$ in the overall mass transfer coefficient when the feed gas rate was increased from 120 to $260 \mathrm{~cm}^{3} / \mathrm{min}$. 


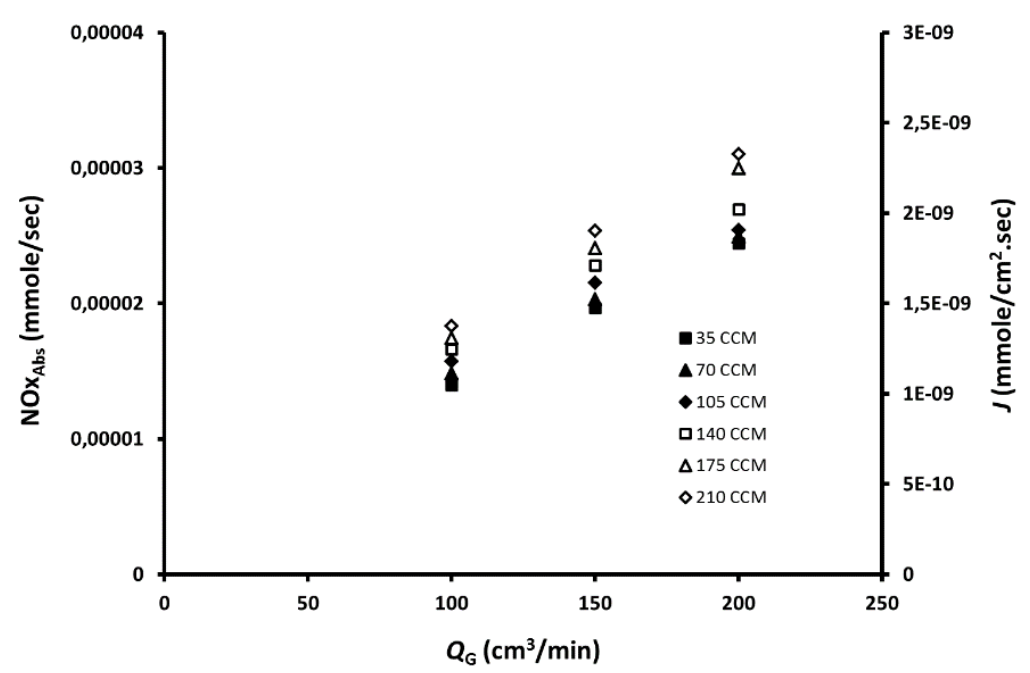

Figure 5 Effects of feed gas flow rate, $Q_{\mathrm{G}}$, on the amount of NOx absorbed, NOx $\mathrm{xbs}_{\mathrm{Ab}}$, and flux, $J$, in the membrane contactor consisting of 2000 fibers and with absorbent flow rates of 35 to $210 \mathrm{~cm}^{3} / \mathrm{min}$ $(\mathrm{CCM})$

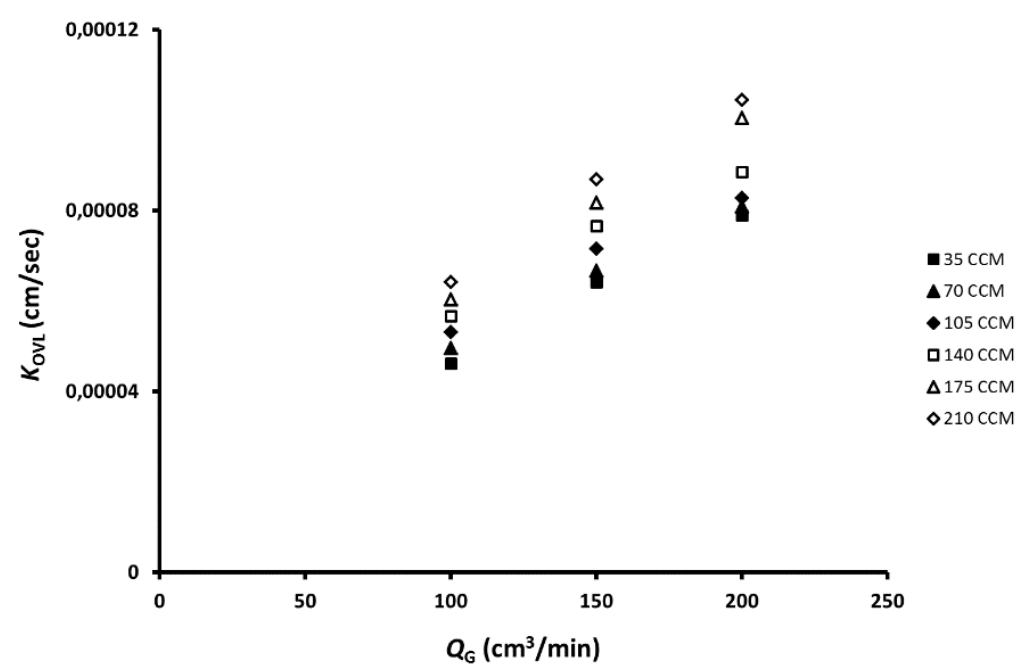

Figure 6 Effects of feed gas flow rate, $Q_{\mathrm{G}}$, on the overall mass transfer coefficient, $\mathrm{K}_{\mathrm{OVL}}$, in the membrane contactor consisting of 2000 fibers and absorbent flow rates of 35 to $210 \mathrm{~cm}^{3} / \mathrm{min}(\mathrm{CCM})$

The dependence of NOx absorption efficiency on the feed gas rate is shown in Figure 7; absorption efficiency is the ratio between the NOx absorbed and the NOx feed flow rate. Increasing the feed gas rate will reduce the efficiency of NOx absorption. The amount of NOx absorbed increases with the increase in the absorbent flow rate, but on the other hand the NOx feed flow rate also increases. The decrease in absorption efficiency was due to the increase in the amount of NOx absorbed, which was not proportional to the increase in the flow rate of the feed gas. NOx absorption efficiency decreased from 35 to $24 \%$ when increasing the feed gas flow rate from 100 to $200 \mathrm{~cm}^{3} / \mathrm{min}$. The same phenomenon was also described by Yan et al. (2007) for a system of $\mathrm{CO}_{2}-\mathrm{N}_{2}-\mathrm{O}_{2}$, in which the absorption efficiency of $\mathrm{CO}_{2}$ using an absorbent of $1 \mathrm{M} \mathrm{MEA}$ solution decreased from 89 to $54 \%$ when the feed gas flow rate increased from 0.21 to $0.56 \mathrm{~m} / \mathrm{s}$. 


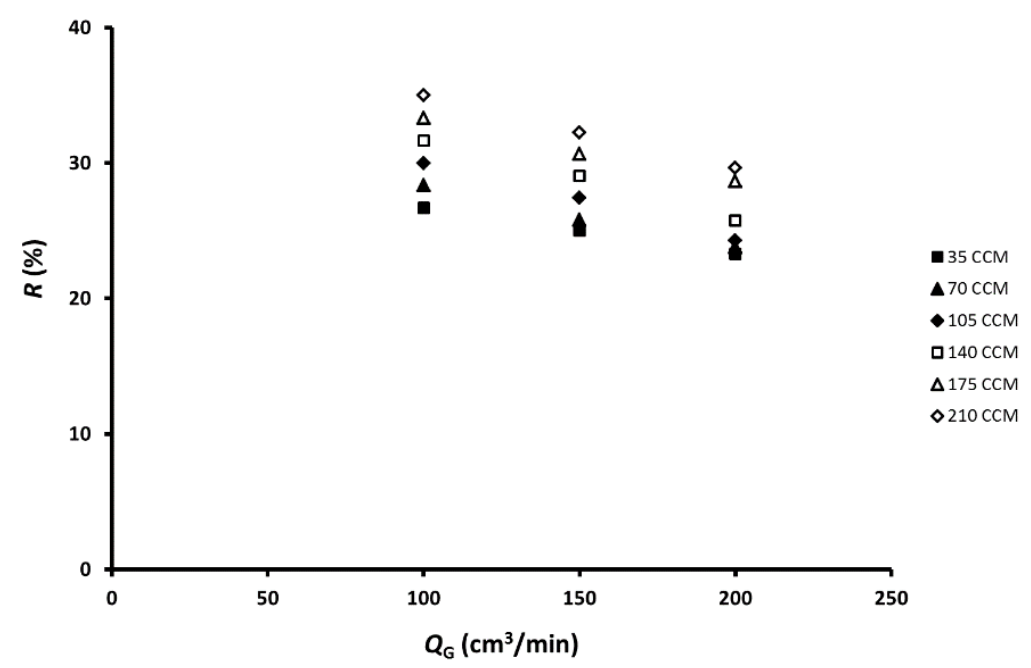

Figure 7 Effects of feed gas flow rate, $Q_{\mathrm{G}}$, on NOx absorption efficiency, $R$, in the membrane contactor consisting of 2000 fibers and absorbent flow rates of 35 to $210 \mathrm{~cm}^{3} / \mathrm{min}$ (CCM)

\section{CONCLUSION}

Nitrogen oxides (NOx) are very hazardous pollutants and can have negative effects on human health and the global environment. Several methods have been applied for NOx removal; however, the temperature applied in these is high. The removal of NOx from air by absorption using a mixture of $\mathrm{H}_{2} \mathrm{O}_{2}$ and $\mathrm{HNO}_{3}$ solutions through hollow fiber membrane contactors at room temperature has been performed in this study. The amount of NOx absorbed, the flux and the overall mass transfer coefficient were enhanced by an increase in the absorbent as well as the feed gas flow rates, due to increased turbulence in the absorbent and gas boundary layers, respectively. The absorption efficiency of NOx increases in line with the absorbent flow rate, but decreases with the feed gas flow rate. An increase in the number of fibers in the membrane contactor will have an incremental effect on the amount of NOx absorbed and removal efficiency, but will have a decreasing effect on the flux and the overall mass transfer coefficient. The highest values of NOx removal efficiency, mass transfer coefficient and flux achieved in the study were $47 \%, 8.7 \times 10^{-5} \mathrm{~cm} \cdot \mathrm{sec}^{-1}$, and $3.1 \times 10^{-5}$ mmole. $\mathrm{cm}^{-2} \cdot \mathrm{sec}^{-1}$, respectively. It is expected that the proposed method could be used as an alternative technique for reducing NOx content in exhaust gas from burning fossil fuels.

\section{ACKNOWLEDGEMENT}

The authors acknowledge the financial support from the PDUPT Grant through Contract No. 422/UN2.R3.1/HKP05.00/2018 and is partially supported by the United States Agency for International Development (USAID) through the Sustainable Higher Education Research Alliance (SHERA) Program for Universitas Indonesia's Scientific Modeling, Application, Research and Training for City-centered Innovation and Technology (SMART CITY) Project, Grant \#AID-497-A-1600004, Sub Grant \#IIE-00000078-UI-1.

\section{REFERENCES}

Ahmad, M.Z., Hashim, H., Yunus, N.A., Lim, J.S., Ho, W.S., Siong, H.C., 2017. A Physical Absorption Assessment of a New Alternative Solvent for Carbon Capture. Chemical Engineering Transactions, Volume 56, pp. 625-630 
Bueno-López, A., Lozano-Castelló, D., McCue, A.J., Anderson, J.A., 2016. NOx Storage and Reduction over Copper-based Catalysts. Part 3: Simultaneous NOx and Soot Removal. Applied Catalysis B: Environmental, Volume 198, pp. 266-275

Cheng, Y., Liu, J., Zhao, Z., Song, W., Wei, Y., 2018. A new 3DOM Ce-Fe-Ti Material for Simultaneously Catalytic Removal of PM and NOx from Diesel Engines. Journal of Hazardous Materials, Volume 342, pp. 317-325

Choi, B., Lee, K.-S., 2014. LNT/CDPF Catalysts for Simultaneous Removal of NOx and PM from Diesel Vehicle Exhaust. Chemical Engineering Journal, Volume 240, pp. 476-486

Dindore, V., Brilman, D., Versteeg, G., 2005. Hollow Fiber, Contactor as a Gas-liquid Model Contactor. Chemical Engineering Science, Volume 60(2), pp. 467-479

Dvořák, R., Chlápek, P., Jecha, D., Puchýř, R., Stehlík, P., 2010. New Approach to Common Removal of Dioxins and NOx as a Contribution to Environmental Protection. Journal of Cleaner Production, Volume 189(9), pp. 881-888

Epling, W.S., Campbell, L.E., Yezerets, A., Currier, N.W., Parks, J.E., 2004. Overview of the Fundamental Reactions and Degradation Mechanisms of NOx Storage/reduction Catalysts. Catalysis Reviews, Volume 46(2), pp. 163-245

Franco, J., Demontigny, D., Kentish, S., Perera, J., Stevens, G., 2008. A Study of the Mass Transfer of $\mathrm{CO}_{2}$ through Different Membrane Materials in the Membrane Gas Absorption Process. Separation Science and Technology, Volume 43(2), pp. 225-244

Granger, P., Parvulescu, V.I., 2011. Catalytic NOx Abatement Systems for Mobile Sources: From Three-way to Lean Burn After-treatment Technologies. Chemical Reviews, Volume 111(5), pp. 3155-3207

Herreros, J.M., George, P., Umar, M., Tsolakis, A., 2014. Enhancing Selective Catalytic Reduction of NOx with Alternative Reactants/promoters. Chemical Engineering Journal, Volume 252, pp. 47-54

Kartohardjono, S., Darmawan, R., Karyadi, M.F., Saksono, N., 2016. $\mathrm{CO}_{2}$ Absorption through Super-hydrophobic Hollow Fiber Membrane Contactors. Journal of Environmental Science and Technology, Volume 9(2), pp. 214-219

Kartohardjono, S., Paramitha, A., Putri, A.A., Andriant, R., 2017a. Effects of Absorbent Flow Rate on $\mathrm{CO}_{2}$ Absorption through a Super Hydrophobic Hollow Fiber Membrane Contactor. International Journal of Technology, Volume 8(8), pp. 1429-1435

Kartohardjono, S., Sembiring, K.A., Rexy, Syandika, R., Ghasani, F., Saksono, N., 2017b. CO 2 Absorption from Its Mixture through Super-hydrophobic Membrane Contactor. Journal of Environmental Science and Technology, Volume 10(1), pp. 25-34

Li, J.-L., Chen, B.-H., 2005. Review of $\mathrm{CO}_{2}$ Absorption using Chemical Solvents in Hollow Fiber Membrane Contactors. Separation and Purification Technology, Volume 41(2), pp. 109-122

Li, Q., Meng, M., Tsubaki, N., Li, X., Li, Z., Xie, Y., Hu, T., Zhang, J., 2009. Performance of Kpromoted Hydrotalcite-derived CoMgAlO Catalysts Used for Soot Combustion, NOx Storage and Simultaneous Soot-NOx Removal. Applied Catalysis B: Environmental, Volume 91(1), pp. 406-415

Li, T., Xu, G., Rong, J., Chen, H., He, C., Giordano, M., Wang, Q., 2016. The Acclimation of Chlorella to High-level Nitrite for Potential Application in Biological NOx Removal from Industrial Flue Gases. Journal of Plant Physiology, Volume 195, pp. 73-79

Liémans, I., Thomas, D., 2013. Simultaneous NOx and SOx Reduction from Oxyfuel Exhaust Gases using Acidic Solutions Containing Hydrogen Peroxide. Energy Procedia, Volume 37, pp. 1348-1356

Nimcharoen, R., Maneeintr, K., Charinpantikul, T., 2018. Measurement of $\mathrm{CO}_{2}$ Absorption in a $4 \mathrm{M}$ Aqueous Solution of 3-Amino-1-Propanol for $\mathrm{CO}_{2}$ Removal. Chemical Engineering Transactions, Volume 63, pp. 193-198 
Pereda-Ayo, B., López-Fonseca, R., González-Velasco, J.R., 2009. Influence of the Preparation Procedure of NSR Monolithic Catalysts on the Pt-Ba Dispersion and Distribution. Applied Catalysis A: General, Volume 363(1-2), pp. 73-80

Wang, D., Teo, W., Li, K., 2004. Selective Removal of Trace $\mathrm{H}_{2} \mathrm{~S}$ from Gas Streams Containing $\mathrm{CO}_{2}$ using Hollow Fibre Membrane Modules/contractors. Separation and Purification Technology, Volume 35(2), pp. 125-131

Wang, S., Xing, J., Zhao, B., Jang, C., Hao, J., 2014. Effectiveness of National Air Pollution Control Policies on the Air Quality in Metropolitan Areas of China. Journal of Environmental Sciences, Volume 26(1), pp. 13-22

Wang, Z., Li, Q., Wang, L., Shangguan, W., 2012. Simultaneous Catalytic Removal of NOx and Soot Particulates over CuMgAl Hydrotalcites Derived Mixed Metal Oxides. Applied Clay Science, Volume 55, pp. 125-130

Yan, S.-p., Fang, M.-X., Zhang, W.-F., Wang, S.-Y., Xu, Z.-K., Luo, Z.-Y., \& Cen, K.-F. 2007. Experimental study on the separation of $\mathrm{CO} 2$ from flue gas using hollow fiber membrane contactors without wetting. Fuel Processing Technology, Volume 88(5), pp. 501-511

You, R., Meng, M., Zhang, J., Zheng, L., Hu, T., Li, X., 2018. A Noble-metal-free SCR-LNT Coupled Catalytic System Used for High-concentration NOx Reduction under Lean-burn Condition. Catalysis Today, Volume 327, pp. 347-356

Yu, J. C.-C., Nguyen, V.-H., Lasek, J., Wu, J.C.S., 2017. Titania Nanosheet Photocatalysts with Dominantly Exposed 001 Reactive Facets for Photocatalytic NOx Abatement. Applied Catalysis B: Environmental, Volume 219, pp. 391-400

Zhang, T., Liu, J., Wang, D., Zhao, Z., Wei, Y., Cheng, K., Jiang, G., Duan, A., 2014. Selective Catalytic Reduction of $\mathrm{NO}$ with $\mathrm{NH}_{3}$ over HZSM-5-supported $\mathrm{Fe}-\mathrm{Cu}$ Nanocomposite Catalysts: The Fe-Cu Bimetallic Effect. Applied Catalysis B: Environmental, Volume 148149, pp. 520-531

Zhao, Y., Sun, X., Fang, H., Liu, F., 2007. Simultaneous Removal of $\mathrm{SO}_{2}$ and NO from Flue Gas using “Oxygen-Enriched” Highly Reactive Absorbent. Environmental Engineering Science, Volume 24(3), pp. 372-382

Zhu, R., Guo, M., Ouyang, F., 2008. Simultaneous Removal of Soot and NOx over Ir-based Catalysts in the Presence of Oxygen. Catalysis Today, Volume 139(1), pp. 146-151

Zouzelka, R., Rathousky, J., 2017. Photocatalytic Abatement of NOx Pollutants in the Air using Commercial Functional Coating with Porous Morphology. Applied Catalysis B: Environmental, Volume 217, pp. 466-476 